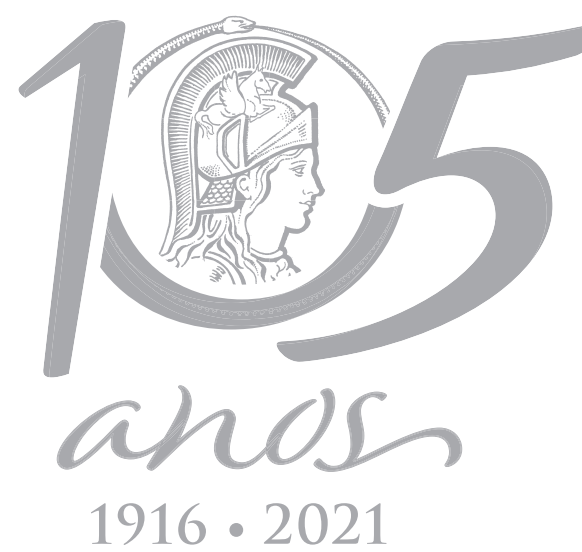

\title{
Use of blend based on an emulsifier, monolaurin, and glycerides of butyric acid in the diet of broilers: impacts on intestinal health, performance, and meat
}

\author{
AMANDA B. ALMEIDA, DENISE N. ARAÚJO, JOÃO V. STRAPAZZON, CLEICIANE \\ RITA, AMANDA DILDA, GIOVANA BALEN, GUILHERME L. DEOLINDO, DANIELA \\ NESI, VALCENIR J.M. FURLAN, GIOVANA PELISSER, RICARDO E. MENDES, MATEUS \\ FRACASSO, ROGER WAGNER, MARCEL M. BOIAGO \& ALEKSANDRO S. DA SILVA
}

\begin{abstract}
The objective of this study was to evaluate whether the addition of a blend based on a-monolaurin mono-, di- and triglycerides of butyric acid, and lysolecithin on the performance even on diets containing reduced inclusion of oil in the diet and without the use of growth-promoting antibiotics of broilers considering the effect on health, performance, and meat. Three treatments were defined: positive control (TP: with enramycin), negative control (TN: no enramycin), and blend (T-FRA: with monolaurin and glycerides of acid butyric minus $0.8 \%$ soybean oil). At 21 days, broilers treated with TP and T-FRA obtained the lower feed conversion ratio (FC); at 35 days, T-FRA broilers obtained lower FC than TN broilers. Cholesterol levels were higher in the blood of T-FRA broilers. On day 42, levels of ROS and TBARS were lower in the intestine, muscles, and liver of T-FRA broilers. Moreover, glutathione S-transferase and total non-enzymatic antioxidants were greater at the intestinal and muscular levels. The T-FRA broilers had a lower percentage of lipids in the meat. The MIC indicated that $111 \mathrm{mg}$ of the blend/ $\mathrm{mL}$ inhibited the growth of E. coli; however, the counts of total coliforms and E. coli in the feces and the broilers' litter did not differ between treatments. In conclusion, the addition of the blend T-FRA in broiler diets was able to improve the feed conversion and maintain the other performance parameters even considering a reduction of $0.8 \%$ in the inclusion of oil.
\end{abstract}

Key words: butyric acid, oxidative stress, hydrolyzed lecithin, glycerol monolaurate

\section{INTRODUCTION}

Brazil is currently the second-largest exporter of chicken meat after the US, and it is expected that by 2029, Brazil will have taken the lead. Currently, the country is in third place in global production of chicken meat up to 13.6 million tons according to Sindorações in 2019. The technology used in the poultry industry has been exploited to optimize production, improve financial results and produce safer and healthier food. As a result, a campaign called for a total ban on antimicrobials in poultry production as a performance enhancer. Indeed, there have been a public call for restricting antimicrobials in animal feed, and several antibiotics have already been banned in various countries. Due to this need for alternatives, the industry has produced natural additives and used them in poultry production, providing favorable conditions for the growth of beneficial microorganisms in the 
gastrointestinal tract. The aim is to provide better digestion and absorption of nutrients and improve the quality of the final products without risking harm to the consumer (Fuini 2001). In particular, functional and enzymatic additives allow the reduction of inclusion of ingredients with similar properties in the feed, consequently, reducing the final cost of poultry feed. These products are marketed in Brazil to replace antibiotics or supplement the birds without losing productivity.

Commercial products manufactured to improve performance feature a blend of ingredients that provide nutrients for the development of enterocytes and, particularly organic acids, phytogenic, and phytobiotic (Galli et al. 2020a, b). Organic short-chain acids can reduce bacterial loads in the digestive tract and improve animal performance (Rocha et al. 2010). Their effects vary with physicalchemical characteristics, buffering capacity of the ingredients that influence intestinal $\mathrm{pH}$, and, consequently, alteration of the heterogeneity of the intestinal microbiota (Dibner \& Buttin 2002, Rick 2003). In the case of organic acids, there is a specific antibacterial effect similar to that of antibiotics, mainly for short-chain organic acids that are particularly effective against $E$. coli, Salmonella, and Campylobacter (Dibner \& Buttin 2002, Rick 2003). According to Adams (1999), the functions of organic acids are broad: producing acidity that acts as a flavoring agent, retarding enzymatic degradation, acting as a chelator preventing or reducing oxidation, and acting directly as a stimulus to enterocyte development with consequent improvement in the animals' weight gain.

Butyric acid is a short-chain organic acid with a direct influence on stimulating the growth of enterocytes, as it is also used as an energy source for these cells. Thus, they help to improve intestinal integrity, acting as a barrier to pathogens and increasing nutrient absorption capacity, which consequently improves animal performance Butyric acid glycerides (mono-, di-and triglycerides of butyric acid) and are stable at $\mathrm{pH}$ and are therefore released directly into the intestine and being more efficient than the free butyric acid salts.

Alpha-monolaurin is a monoester formed from lauric acid (C12:0); it is considered a mediumchain fatty acid with antimicrobial and antiviral activity (Freitas et al. 2009). Alpha-monolaurin is mainly active against Gram-positive pathogenic microorganisms (Batovska et al. 2009) because it exerts a bactericidal and antiviral effect by solubilizing the lipid envelope of pathogens, causing this envelope to disintegrate (Lieberman et al. 2006). Alpha-monolaurin, also called glycerol monolaurate (GML), is generally recognized as safe by the United States Food and Drug administration (Jiang et al. 2018). It has strong antimicrobial effects, especially against Gram-positive bacteria, by suppressing the growth and virulence of various bacteria, fungi, and viruses in vitro (Batovska et al. 2009). Recent studies have shown that GML improved productivity, health, feed efficiency, and poultry quality and is therefore considered a promising feed additive in animal production (Fortuoso et al. 2019, Mustafa et al. 2019).

Emulsifiers are active agents with amphiphilic characteristics (Zhao et al. 2015) that facilitate the mixing of oil and water, reducing the surface tension and the energy required to form the emulsion (Araújo 2011), thereby supporting digestion processes. According to Fonseca et al. (2018), emulsifiers are responsible for facilitating and increasing the utilization of fats as they facilitate the formation of micelles for lipid enzymes to perform digestion. Among the emulsifiers most used by the food industry are proteins (whey, soy, egg), phospholipids, and small surfactant molecules (molecular weight between 500 to 1300 Daltons) such as polysorbates and lecithins (Araújo 2011). The addition of emulsifiers in the diet can increase the net energy provided by oils and consequently reduce their inclusion and the costs of feed; this was also the focus 
of this study, given the high cost of soy and its derivatives. The objective of this study was to determine whether the inclusion of a blend based on mono-, di- and triglycerides of butyric acid, $\alpha$-monolaurin, glycerol, and an emulsifier would substitute for a conventional antibiotic as a performance enhancer. We also measured its effects on zootechnical performance, intestinal health, metabolism, and meat.

\section{MATERIALS AND METHODS}

\section{Ethics committee}

The ethics committee approved the project on animals' use in research (CEUA no 7175220620) at the Universidade do Estado de Santa Catarina (UDESC).

\section{Blend}

The blend used in this study a mixture containing $\alpha$-monolaurin, mono-, di- and triglycerides of butyric acid, and hydrolyzed lecithin (lysolecithin) - T-FRA.

\section{Formulation of diets}

The diets were formulated per phase of the production cycle (initial, growth and termination) and were based on corn and soy, following the recommendations of the Brazilian Table (Rostagno et al. 2011). All diets contained salinomycin in the starter and grower diet. Enramycin was used only in the positive control group as a conventional growth promoter and added to starter and grower diet $(10 \mathrm{mg} / \mathrm{kg})$. The negative control group differed from the positive control group by removing enramycin from the diet. The nutritional matrix of the tested blend allowed a reduction of approximately $0.8 \%$ of soy oil in the diet only in the treatment group. The blend was added at a dosage of $1 \mathrm{~kg} /$ ton to the basal diet of its respective treatment group, as detailed in Table I.

\section{Characterization of the experimental environment}

The study was conducted in the experimental poultry facility of the UDESC Oeste poultry sector. The birds were housed in boxes (1.0 $\mathrm{x}$ $1.8 \mathrm{~m}$ ) with beds of reused wood shavings from the $9^{\text {th }}$ batch. Feed and water were provided ad libitum via tubular feeders and drinking nipples. Temperature was regulated with electric lamps and gas hoods according to the local temperature. Light management followed the recommendations of the lineage manual.

\section{Animals and experimental design}

A total of 225 one-day-old Ross chicks (males) were purchased at the start of this study. The experimental design was completely randomized, containing three treatments, with five repetitions of 15 broilers each. The following treatments were defined: a) positive control (TP) diet containing conventional basal diet with enramycin; b) negative control (TN) containing basal diet without the antibiotic growth promoter enramycin; and c) blend (T-FRA) at a dosage of $1 \mathrm{~kg} /$ ton added to the basal diet without enramycin and where soybean oil was reduced with $0.8 \%$ compared to the TP and TN diets.

\section{Minimum inhibitory concentration}

The minimum inhibitory concentration (MIC) of the antimicrobial blend was determined in vitro. The analysis was performed according to the CLSI guidelines, in $10^{-1}$ to $10^{-5}$ dilutions, in the proportion of $1 \mathrm{~g}$ of the blend in $9 \mathrm{~mL}$ of Müller Hinton solution for the $10^{-1}$ dilution; the remaining dilutions were followed successively until achieving $10^{-5}$ of Escherichia coli from poultry litter. 
Table I. Ingredients and basal diet for each phase of the production cycle of the three treatments.

POSITIVE CONTROL - GROUP TP

\begin{tabular}{|c|c|c|c|}
\hline \multirow[t]{2}{*}{ Ingredients (kg/ton) } & \multicolumn{3}{|c|}{ Age (days) } \\
\hline & $1-21$ & $22-35$ & $36-42$ \\
\hline Corn & 551.51 & 580.05 & 621.35 \\
\hline Soybean meal & 373.01 & 337.00 & 298.22 \\
\hline Soy oil & 39.05 & 49.19 & 49.70 \\
\hline Dicalcium phosphate & 12.71 & 13.00 & 112.25 \\
\hline Calcitic limestone & 11.42 & 9.28 & 8.00 \\
\hline Ionized salt & 4.86 & 4.23 & 3.95 \\
\hline DL-methionine - 99\% & 2.91 & 2.82 & 2.50 \\
\hline L-lysine - 78\% & 2.03 & 1.95 & 2.63 \\
\hline L-threonine - 99\% & 0.50 & 0.48 & 0.40 \\
\hline Premix of vitamins and minerals ${ }^{1}$ & 2.00 & 2.00 & 2.00 \\
\hline Enramycin (mg/kg) & 10 & 10 & - \\
\hline Salinomycin $(\mathrm{mg} / \mathrm{kg})$ & 64 & 64 & - \\
\hline Calculated chemical composition & 100 & 100 & 100 \\
\hline Energy (kcal/kg) & 3050 & 3150 & 3200 \\
\hline Crude protein (\%) & 21.20 & 19.80 & 18.40 \\
\hline Calcium (\%) & 0.84 & 0.76 & 0.66 \\
\hline Available phosphorus (\%) & 0.40 & 0.35 & 0.31 \\
\hline Digestible lysine (\%) & 1.22 & 1.13 & 1.06 \\
\hline Digestible methionine (\%) & 0.47 & 0.45 & 0.42 \\
\hline Methionine + digestible cysteine (\%) & 0.88 & 0.83 & 0.77 \\
\hline Digestible threonine (\%) & 0.79 & 0.73 & 0.69 \\
\hline Digestible tryptophan (\%) & 0.21 & 0.20 & 0.19 \\
\hline Sodium (\%) & 0.21 & 0.20 & 0.19 \\
\hline
\end{tabular}

NEGATIVE CONTROL - GROUP TN

\begin{tabular}{|c|c|c|c|}
\hline Ingredients (kg/ton) & \multicolumn{3}{|c|}{ Age (days) } \\
\hline & $\mathbf{1 - 2 1}$ & $\mathbf{2 2 - 3 5}$ & $\mathbf{3 6 - 4 5}$ \\
\hline Corn & 551.51 & 580.05 & 621.35 \\
\hline Soybean meal & 373.01 & 337.00 & 298.22 \\
\hline Soy oil & 39.05 & 49.19 & 49.70 \\
\hline Dicalcium phosphate & 12.71 & 13.00 & 112.25 \\
\hline Calcite limestone & 11.42 & 9.28 & 8.00 \\
\hline Ionized salt & 4.86 & 4.23 & 3.95 \\
\hline DL-Methionine - 99\% & 2.91 & 2.82 & 2.50 \\
\hline L-lysine - 78\% & 2.03 & 1.95 & 2.63 \\
\hline L-threonine - 99\% & 0.50 & 0.48 & 0.40 \\
\hline Premix of vitamins and minerals & 2.00 & 2.00 & 2.00 \\
\hline Salinomycin (mg/kg) & 64 & 64 & - \\
\hline Calculated chemical composition & 100 & 100 & 100 \\
\hline Energy (kcal/kg) & 3050 & 3150 & 3200 \\
\hline
\end{tabular}


Table I. Continuation.

\begin{tabular}{|c|c|c|c|}
\hline Crude protein (\%) & 21.20 & 19.80 & 18.40 \\
\hline Calcium (\%) & 0.84 & 0.76 & 0.66 \\
\hline Available phosphorus (\%) & 0.40 & 0.35 & 0.31 \\
\hline Digestible lysine (\%) & 1.22 & 1.13 & 1.06 \\
\hline Digestible methionine (\%) & 0.47 & 0.45 & 0.42 \\
\hline Methionine + digestible cysteine (\%) & 0.88 & 0.83 & 0.77 \\
\hline Digestible threonine (\%) & 0.79 & 0.73 & 0.69 \\
\hline Digestible tryptophan (\%) & 0.21 & 0.20 & 0.19 \\
\hline Sodium (\%) & 0.21 & 0.20 & 0.19 \\
\hline
\end{tabular}

\section{ANTIMICROBIAL BLEND - GROUP T-FRA}

\begin{tabular}{|c|c|c|c|}
\hline \multirow[t]{2}{*}{ Ingredients (kg/ton) } & \multicolumn{3}{|c|}{ Age (days) } \\
\hline & $1-21$ & $22-35$ & $36-42$ \\
\hline Corn & 551.51 & 580.05 & 621.35 \\
\hline Soybean meal & 373.01 & 337.00 & 298.22 \\
\hline Soy oil & 31.05 & 41.19 & 41.70 \\
\hline Kaolin & 7.00 & 7.00 & 7.00 \\
\hline T-FRA ${ }^{1}$ & 1.00 & 1.00 & 1.00 \\
\hline Dicalcium phosphate & 12.71 & 13.00 & 112.25 \\
\hline Calcite limestone & 11.42 & 9.28 & 8.00 \\
\hline Ionized salt & 4.86 & 4.23 & 3.95 \\
\hline DL-methionine - 99\% & 2.91 & 2.82 & 2.50 \\
\hline L-lysine - 78\% & 2.03 & 1.95 & 2.63 \\
\hline L-threonine - 99\% & 0.50 & 0.48 & 0.40 \\
\hline Premix of vitamins and minerals ${ }^{2}$ & 2.00 & 2.00 & 2.00 \\
\hline Salinomycin (mg/kg) & 64 & 64 & - \\
\hline Calculated chemical composition & 100 & 100 & 100 \\
\hline Energy (kcal/kg) & 3050 & 3150 & 3200 \\
\hline Crude protein (\%) & 21.20 & 19.80 & 18.40 \\
\hline Calcium (\%) & 0.84 & 0.76 & 0.66 \\
\hline Available phosphorus (\%) & 0.40 & 0.35 & 0.31 \\
\hline Digestible lysine (\%) & 1.22 & 1.13 & 1.06 \\
\hline Digestible methionine (\%) & 0.47 & 0.45 & 0.42 \\
\hline Digestible methionine + cysteine (\%) & 0.88 & 0.83 & 0.77 \\
\hline Digestible threonine (\%) & 0.79 & 0.73 & 0.69 \\
\hline Digestible tryptophan (\%) & 0.21 & 0.20 & 0.19 \\
\hline Sodium (\%) & 0.21 & 0.20 & 0.19 \\
\hline
\end{tabular}

${ }^{1} \alpha$-Monolaurin (> $25 \%$ ), Mono-, di-, and triglycerides of butryric acid ( $>21 \%$ ), glycerol $(<5 \%)$, emulsifier hydrolyzed lecithins $(180000 \mathrm{mg} / \mathrm{kg})$, Binder Silicic acid, precipitated and dried $(260000 \mathrm{mg} / \mathrm{kg})$.

${ }^{2}$ Minimal vitamin and mineral levels per kg of product: vitamin A (5.000.000 UI); vitamin D3 (1.000.000 IU); vitamin E (15.000 UI); vitamin K3 (1.500 mg); vitamin B1 (1.500 mg); vitamin B2 (3.000 mg); vitamin B6 (2.000 mg); vitamin B12 (7.000 mcg); folic acid (500 $\mathrm{mg}$ ); nicotinic acid (15 g); pantothenic acid (7000 mcg); choline ( $80 \mathrm{~g})$; biotin (100 mg); Copper (10 g); iron (50 g); iodine (1.000 mg); manganese (80 g); selenium (300 mg); zinc (70 g); minimum humidity (20 g); maximum mineral matter (980 g). 


\section{Zootechnical performance}

The body weights of the broilers were measured on days 1, 21, 35, and 42. Based on this, weight gain and average weight gain were calculated, and the amount of feed consumed by the broilers was measured. This information allowed the calculation of feed conversion ratio ( $F C=$ feed consumption/weight gain). The productive efficiency index (PEI) the methodology described by Galli et al. (2020a).

\section{Microbiological analysis}

Microbiological analyses were performed at 21 and 42 days of the experiment. Fresh feces were collected from the broilers' cloaca. Also, samples of a five-point bed mix from each group were taken. These samples were diluted to colonyforming units (CFU) $\times 10^{6}$. The samples were deposited on Petrifilm and were placed in an oven of 38 o C for 24 hours, followed by counting of total coliforms and E. coli.

\section{Serum biochemistry}

Blood was collected from the broilers ( $n=8$ per group) through the ulnar vein on day 42 of the experiment to measure serum levels of glucose, cholesterol, triglycerides, total proteins, albumin, and urea, using semi-automatic equipment (Bioplus $2000^{\circledR}$ ) with commercial kits (Gold Analisa ${ }^{\circledR}$ ). Globulin values were calculated as the difference between total protein and albumin.

\section{Oxidant/antioxidant profiles}

Broilers were slaughtered at 42 days of age, and fragments of the muscle (pectoralis major), liver, and intestine (jejunum) were collected. The tissues were homogenized in $10 \mathrm{mmol}$ Tris$\mathrm{HCl}(\mathrm{pH}$ 7.2) for measurements of oxidants and antioxidants. The samples were stored in tubes and frozen at $-20{ }^{\circ} \mathrm{C}$ for later analysis.
The oxidation of 2'-7'-dichlorofluorescein (DCFH) levels was determined in homogeneous tissue as an index of peroxide produced by cells following the method described by Ali et al. (1992), to determine levels of ROS. The levels of lipid peroxidation were determined by levels of thiobarbituric acid reactive substances (TBARS), measured by the absorbance at $532 \mathrm{~nm}$, according to the method described by Ohkawa et al. (1978). The gluthatione S-transferase (GST) tissue homogenate was based on a spectrophotometer according to Habig et al. (1974), as well as determining total thiol levels (Costa et al. 2006).

\section{Fatty acid (FA) profile}

Samples of broiler meat and feed were taken and analyzed for fatty acid profile. Following the method described by Bligh \& Dyer (1959), the lipid extraction was carried out by adding $4 \mathrm{~g}$ of samples, $6.4 \mathrm{~mL}$ of water, $16 \mathrm{~mL}$ of methanol, and $8 \mathrm{~mL}$ of chloroform into $50 \mathrm{~mL}$ polypropylene tubes, and mechanical shaking the tubes for 60 min. After that, $8 \mathrm{~mL}$ of chloroform and $8 \mathrm{~mL}$ of $\mathrm{Na}_{2} \mathrm{SO}_{4} 1.5 \%$ solution were added to promote a biphasic system. This mixture was shaken for 2 min and then centrifuged for $5 \mathrm{~min}$ at $3000 \mathrm{rpm}$. Lipids obtained from the chloroform phase were subjected to fatty acid analysis before solvent drying by $\mathrm{N}_{2}$ flow.

FA methylation from the lipid fraction was performed using the transesterification/ esterification method proposed by Hartman \& Lago (1973). To the extracted lipids, $1 \mathrm{~mL}$ of 0.4 $\mathrm{M} \mathrm{KOH}$ methanolic solution was added in a test tube and shaken in a vortex for $1 \mathrm{~min}$. Samples were kept in a water bath for 10 min at boiling point. Subsequently, samples were cooled at room temperature, and $3 \mathrm{~mL}$ of $1 \mathrm{M} \mathrm{H}_{2} \mathrm{SO}_{4}$ methanolic solution was added. The tubes were shaken in a vortex and placed in a water bath for $10 \mathrm{~min}$. After cooling, $2 \mathrm{~mL}$ of hexane was added 
and centrifuged at $5000 \mathrm{rpm}$ for $5 \mathrm{~min}$. Finally, hexane with the fatty acid methyl esters (FAME) was subjected to chromatography analysis.

The FAME determination was carried out in a gas chromatograph model 3400 CX equipped with a flame ionization detector (Varian, Palo Alto, CA). One microliter of sample was injected in a split/splitless injector, operating in split (1:25) mode at $250^{\circ} \mathrm{C}$. Hydrogen was used as carrier gas at a constant pressure of 25 psi. The separation of FAME was carried out using an HP88 chromatography column $(100 \mathrm{~m} \times 0.25 \mathrm{~mm}$; 0.20- $\mu$ m film, Agilent, J \& W, Folsom, CA, USA). The initial oven temperature was programmed at 50 ${ }^{\circ} \mathrm{C}$ for $1 \mathrm{~min}$ and increased to $185^{\circ} \mathrm{C}$, at $15^{\circ} \mathrm{C} /$ min. Then, the temperature was increased to 195 ${ }^{\circ} \mathrm{C}$, at a rate of $0.5^{\circ} \mathrm{C} / \mathrm{min}$. Finally, temperature was raised up to $230{ }^{\circ} \mathrm{C}$ by $15{ }^{\circ} \mathrm{C} / \mathrm{min}$, and maintained for $10 \mathrm{~min}$ in isothermal conditions. The detector temperature was kept constant at $250^{\circ} \mathrm{C}$. The FAME compounds were identified by comparing experimental retention times with those from authentic standards (FAME Mix-37, Sigma Aldrich, St. Louis, MO). The results were presented as a percentage of each FA identified in the lipid fraction, considering the chain size equivalent response factor and a conversion factor of the ester to the respective acid for each FAME applied to FID, according to Visentainer (2012). The results of the fatty acid profile in the feed are presented in Supplementary Material (Table SI).

\section{Intestinal morphometry}

Intestinal jejunal samples were collected (days 21 and 42) and maintained in flasks with 10\% formaldehyde solution. Slides with histological sections were stained with hematoxilinaeosina (H\&E). Under a light microscope, the morphological structures of the intestinal portions were evaluated. In the samples of jejunum, villus length and crypt depth were determined according to Caruso \& Demonte (2005). Histological images of the slides were captured using a digital micro-camera (Electronic Eyepiece Camera Video) attached to a biological trinocular microscope (model TNB-41T-PL, OPTON) and a specific program for capturing histological images (Images J). Details of the methodology used to measure villus length and crypt depth were described by Galli et al. (2020a).

\section{Statistical analysis}

The data were first analyzed descriptively. The data were then subjected to normality testing; the bacterial count variables needed to be transformed to logarithms for normalization. Then, a variance analysis test was applied, followed by the Tukey test. Differences were considered significant when $\mathrm{P} \leq 0.05$.

\section{RESULTS}

\section{Minimum inhibitory concentration}

The MIC indicated inhibition of the bacterium only in the $10^{-1}$ dilution of the blend; that is, 111 $\mathrm{mg}$ of the product per $\mathrm{mL}$ is needed to have antimicrobial action on the Gram-negative bacteria E. coli.

\section{Zootechnical performance}

There was no significant $(P>0.05)$ effect of treatment on body weight (Table II) and productive efficiency index (Table III). At 21 days of age, broilers from the negative control group consumed more feed than the positive control, which consequently resulted in a higher feed conversion ratio $(P=0.01$; Table $\mathrm{II})$. Broilers in the T-FRA group at 35 days showed a reduced feed conversion ratio than TN but similar to TP $(P=0.05 ;$ Table II). At 42 days, there was no difference between treatments in zootechnical performance variables ( $P$ > 0.05; Table II). 
Table II. Performance (mean and standard deviation) of broilers fed a blend T-FRA compared to a positive control group (TP) and a negative control group (TN).

\begin{tabular}{|c|c|c|c|}
\hline \multicolumn{4}{|l|}{1 to 21 days } \\
\hline & Body weight (g) & Feed consumption (g) & Feed conversion ratio \\
\hline TN: Negative control & $937 \pm 24$ & $1281 \pm 51 \mathrm{~A}$ & $1.44 \pm 0.09 \mathrm{~A}$ \\
\hline TP: Positive control & $884 \pm 43$ & $1138 \pm 66 \mathrm{~B}$ & $1.36 \pm 0.03 B$ \\
\hline T-FRA: blend & $898 \pm 34$ & $1199 \pm 74 \mathrm{AB}$ & $1.41 \pm 0.05 \mathrm{AB}$ \\
\hline P-value & 0.092 & 0.01 & 0.01 \\
\hline \multicolumn{4}{|l|}{1 to 35 days } \\
\hline & Body weight (g) & Feed consumption (g) & Feed conversion ratio \\
\hline TN: Negative control & $2454 \pm 111$ & $3613 \pm 141$ & $1.50 \pm 0.02 \mathrm{~A}$ \\
\hline TP: Positive control & $2482 \pm 84$ & $3584 \pm 216$ & $1.46 \pm 0.06 \mathrm{AB}$ \\
\hline T-FRA: Blend & $2462 \pm 130$ & $3477 \pm 242$ & $1.44 \pm 0.04 \mathrm{~B}$ \\
\hline P-value & 0.64 & 0.57 & 0.05 \\
\hline \multicolumn{4}{|l|}{1 to 42} \\
\hline & Body weight (g) & Feed consumption (g) & Feed conversion ratio \\
\hline TN: Negative control & $3222 \pm 128$ & $5100 \pm 335$ & $1.60 \pm 0.06$ \\
\hline TP: Positive control & $3260 \pm 74$ & $5357 \pm 223$ & $1.66 \pm 0.04$ \\
\hline T-FRA: Blend & $3280 \pm 127$ & $5179 \pm 182$ & $1.60 \pm 0.03$ \\
\hline P-value & 0.21 & 0.10 & 0.25 \\
\hline
\end{tabular}

Different letters in the same column indicate a significant difference between groups using the Tukey test and considering $\mathrm{P} \leq$ 0.05 .

Table III. Index of productive efficiency of broilers fed with a T-FRA compared to a positive control (TP) and negative control (TN) group.

\begin{tabular}{|c|c|}
\hline & $\begin{array}{c}\text { Productive Efficiency } \\
\text { Index }\end{array}$ \\
\hline TN: Negative control & 466.5 \\
\hline TP: Positive control & 454.9 \\
\hline $\begin{array}{c}\text { T-FRA: Antimicrobial } \\
\text { blend }\end{array}$ & 468.5 \\
\hline P-value & 0.187 \\
\hline
\end{tabular}

\section{Microbiological of bedding and feces}

The counts of total coliforms and E. coli in the feces and the broilers' litter did not differ between treatments $(P>0.05$; Table IV).

\section{Serum biochemistry}

There was no effect of treatments on uric acid levels, albumin, cholesterol, glucose, total proteins, or triglycerides $(P>0.05)$. Cholesterol levels were higher in the T-FRA group than in the TN group ( $P=0.05$; Table $V)$. 
Table IV. Counting of total coliforms and colonies of Escherichia coli in broiler litter and feces of broilers fed a T-FRA at 21 and 42 days of the experiment compared to a positive control (TP) and negative control (TN) group.

\begin{tabular}{|c|c|c|c|c|c|}
\hline & Collection day & TN & TP & T-FRA & P-value \\
\hline BROILER LITTER & & & & & \\
\hline Total coliforms & 21 & $38.8 \pm 27.9$ & $38.4 \pm 30$ & $0.2 \pm 7.6$ & 0.11 \\
\hline$\left(\right.$ CFU $\left.\times 10^{6}\right)$ & 42 & $0.0 \pm 0.0$ & $0.6 \pm 0.8$ & $0.0 \pm 0.0$ & 0.92 \\
\hline & & & & $3.6 \pm 2.3$ & 0.08 \\
\hline E. coli & 21 & $9.6 \pm 7.1$ & $10.4 \pm 6.0$ & $0.0 \pm 0.0$ & 0.94 \\
\hline
\end{tabular}

\section{BROILER FECES}

\begin{tabular}{|c|c|c|c|c|c|}
\hline & Collection day & TN & TP & T-FRA & P-value \\
\hline Total coliforms & 21 & $65.7 \pm 50.1$ & $57.7 \pm 53.5$ & $19.1 \pm 9.1$ & 0.35 \\
\hline$\left(\right.$ CFU $\left.\times 10^{6}\right)$ & 42 & $0.4 \pm 0.5$ & $2.6 \pm 2.4$ & $0.4 \pm 0.8$ & 0.89 \\
\hline & & & & & \\
\hline E. coli & 21 & $36.6 \pm 32.0$ & $21.0 \pm 22.3$ & $15.0 \pm 13.7$ & 0.06 \\
\hline$\left(\right.$ CFU $\left.\times 10^{6}\right)$ & 42 & $0.2 \pm 0.4$ & $1.6 \pm 1.2$ & $0.4 \pm 0.8$ & 0.56 \\
\hline
\end{tabular}

Table V. Serum metabolic biochemistry of broilers fed T-FRA at 42 days of the experiment compared to a positive control group (TP) and a negative control group (TN).

\begin{tabular}{|c|c|c|c|c|}
\hline & TN & TP & T-FRA & P-value \\
\hline Total protein $(\mathrm{g} / \mathrm{dL})$ & $4.62 \pm 0.41$ & $4.84 \pm 0.14$ & $4.54 \pm 0.27$ & 0.61 \\
\hline Albumin $(\mathrm{g} / \mathrm{dL})$ & $1.38 \pm 0.12$ & $1.22 \pm 0.17$ & $1.32 \pm 0.20$ & 0.24 \\
\hline Globulin $(\mathrm{g} / \mathrm{dL})$ & $3.24 \pm 0.21$ & $3.62 \pm 0.17$ & $3.22 \pm 0.23$ & 0.07 \\
\hline Uric acid $(\mathrm{mg} / \mathrm{dL})$ & $3.54 \pm 1.05$ & $3.20 \pm 1.22$ & $3.42 \pm 1.05$ & 0.59 \\
\hline Triglycerides $(\mathrm{mg} / \mathrm{dL})$ & $89.4 \pm 23.2$ & $59.2 \pm 32.0$ & $74.2 \pm 24.6$ & 0.15 \\
\hline Cholesterol $(\mathrm{mg} / \mathrm{dL})$ & $115 \pm 9.73^{\mathrm{b}}$ & $132 \pm 24.8^{\mathrm{ab}}$ & $147 \pm 15.3^{\mathrm{a}}$ & $\mathbf{0 . 0 5}$ \\
\hline Glucose $(\mathrm{mg} / \mathrm{dL})$ & $260 \pm 14.1$ & $272 \pm 19.7$ & $277 \pm 20.2$ & 0.21 \\
\hline
\end{tabular}

Different letters on the same line indicate a significant difference between groups using the Tukey test and considering $\mathrm{P} \leq 0.05$.

\section{Oxidant/antioxidant profile}

The oxidant and antioxidant profiles in the intestine, muscles, and liver are presented in Table VI. Levels of ROS in the intestine of broilers in the T-FRA group were higher on day 21 and lower on day 42 compared to TN $(P=0.001)$. In T-FRA broilers lower ROS levels in the muscles were found compared to other treatments; and in the liver, ROS levels of the T-FRA broilers were similar to other treatments $(P=0.013)$. However, the oxidative variable levels were major in the liver of TP broilers compared to TN. The TBARS levels at 42 days of the intestine were lower in T-FRA broilers compared to TP and TN broilers ( $P$ $=0.011)$. At day 21, TBARS levels of the intestine and muscles, and liver (day 42) did not differ between treatments $(P>0.05)$. The GST activity was higher in the intestines of T-FRA broilers compared to TN (days 21 and 42), just as it was 
Table VI. Oxidizing and antioxidant status in the intestine (day 21 and 42), muscle (day 42), and liver (day 42) of broilers fed with a T-FRA compared to a positive control (TP) and negative control (TN) group.

\begin{tabular}{|c|c|c|c|c|c|}
\hline & Bird age & TN & TP & T-FRA & P-value \\
\hline Intestinal ROS (x $10^{3} \mathrm{U}$ DCFH/mg protein) & 21 & $4.58 \pm 0.9^{b}$ & $6.59 \pm 2.1^{\mathrm{ab}}$ & $10.9 \pm 4.7^{\mathrm{a}}$ & 0.001 \\
\hline Intestinal ROS (x $10^{3} \mathrm{U}$ DCFH/mg protein) & 42 & $39.3 \pm 6.4^{\mathrm{a}}$ & $25.9 \pm 7.2^{b}$ & $26.8 \pm 5.7^{b}$ & 0.001 \\
\hline Muscle ROS (x $10^{2} \cup \mathrm{DCFH} / \mathrm{mg}$ protein) & 42 & $11.0 \pm 2.4^{\mathrm{a}}$ & $10.8 \pm 3.2^{\mathrm{a}}$ & $5.4 \pm 2.0^{b}$ & 0.001 \\
\hline Liver ROS (x $10^{3} \cup \mathrm{DCFH} / \mathrm{mg}$ protein) & 42 & $2.97 \pm 1.0^{b}$ & $6.36 \pm 1.7^{\mathrm{a}}$ & $5.93 \pm 2.8^{\mathrm{ab}}$ & 0.013 \\
\hline Intestinal TBARS ( $\mu$ mol MDA/mg protein) & 21 & $0.55 \pm 0.22$ & $0.64 \pm 0.21$ & $0.72 \pm 0.25$ & 0.47 \\
\hline Intestinal TBARS ( $\mu$ mol MDA/mg protein) & 42 & $0.92 \pm 0.28^{a}$ & $0.99 \pm 0.32^{\mathrm{a}}$ & $0.45 \pm 0.14^{b}$ & 0.011 \\
\hline Muscle TBARS ( $\mu$ mol MDA/mg protein) & 42 & $0.26 \pm 0.06$ & $0.38 \pm 0.13$ & $0.26 \pm 0.05$ & 0.19 \\
\hline Liver TBARS ( $\mu$ mol MDA/mg protein) & 42 & $0.35 \pm 0.07$ & $0.40 \pm 0.09$ & $0.45 \pm 0.13$ & 0.24 \\
\hline Intestinal GST ( $\mu$ mol Cdnb/min/mg protein) & 21 & $399 \pm 61^{b}$ & $537 \pm 63^{\mathrm{a}}$ & $541 \pm 72^{a}$ & 0.05 \\
\hline Intestinal GST $\mu \mathrm{mol}$ Cdnb/min/mg protein) & 42 & $416 \pm 50^{b}$ & $451 \pm 97^{a b}$ & $589 \pm 105^{a}$ & 0.013 \\
\hline Muscle GST ( $\mu$ mol Cdnb/min/mg protein) & 42 & $387 \pm 32^{\mathrm{a}}$ & $334 \pm 63^{\mathrm{ab}}$ & $278 \pm 41^{b}$ & 0.001 \\
\hline Live GST (x $10^{2} \mu \mathrm{mol}$ MDA/mg protein) & 42 & $10.5 \pm 2.4$ & $9.97 \pm 1.5$ & $8.96 \pm 2.8$ & 0.36 \\
\hline Intestinal thiols ( $\mu \mathrm{mol} \mathrm{SH} / \mathrm{mg}$ protein) & 21 & $1.10 \pm 0.46$ & $0.94 \pm 0.35$ & $0.76 \pm 0.36$ & 0.294 \\
\hline Intestinal thiols ( $\mu \mathrm{mol} \mathrm{SH} / \mathrm{mg}$ protein) & 42 & $1.13 \pm 0.48^{b}$ & $0.83 \pm 0.36^{b}$ & $2.16 \pm 0.63^{\mathrm{a}}$ & 0.050 \\
\hline Muscle thiols ( $\mu \mathrm{mol} \mathrm{SH} / \mathrm{mg}$ protein) & 42 & $0.43 \pm 0.17^{b}$ & $0.72 \pm 0.2^{\mathrm{a}}$ & $0.74 \pm 0.19^{a}$ & 0.012 \\
\hline Liver thiols ( $\mu \mathrm{mol} \mathrm{SH} / \mathrm{mg}$ protein) & 42 & $0.77 \pm 0.18^{b}$ & $0.86 \pm 0.28^{b}$ & $1.37 \pm 0.29^{a}$ & 0.001 \\
\hline
\end{tabular}

${ }^{a, b}$ Different letters on the same line indicate a significant difference between groups using the Tukey test and considering $\mathrm{P} \leq$ 0.05 .

higher in TP birds compared to TN on day 21 ( $P$ $=0.013)$.

In contrast, GST activity in the muscle of broilers from T-FRA was lower than TN broilers ( $P$ $=0.001$ ). At 42, thiol levels (total non-enzymatic antioxidants) were higher in the intestine, muscles, and liver of the T-FRA group than the TN group $(P<0.05)$. The levels of thiols were higher in the intestine and liver of the broilers of T-FRA than TP $(P<0.05)$.

\section{Fatty acid profile in feed and meat}

In the feed, we observed a lower percentage of total lipids than was found in the feed (Table SI), but without the effect of the additive in the feed for the profile of total saturated and unsaturated fatty acids. Some specific fatty acids differed between treatments; lauric acid and palmitic acid were found in higher concentrations in the T-FRA diet. On the other hand, behenic acid was found at a higher concentration in the diet of TN broilers compared to other treatments (Table $\mathrm{SI})$.

In meat, the percentage of total lipids was lower in TN and T-FRA broilers compared to TP broilers ( $P=0.001$; Table VII). The total concentration of saturated fatty acids was higher $(P=0.015)$, and the concentration of polyunsaturated fatty acids was lower in meat from TN and T-FRA broilers compared to TP ( $\mathrm{P}=$ 0.010). The percentage of monounsaturated fatty acids showed no difference between treatments 
Table VII. Fatty acid profile and total lipids in the meat of broilers fed with an blend (T-FRA) compared to a positive control (TP) and negative control (TN) group.

\begin{tabular}{|c|c|c|c|c|c|}
\hline Meat fatty acid profile & TN & TP & T-FRA & CV & Valor $\mathbf{P}$ \\
\hline C12:0 - lauric acid & $0.051^{b}$ & $0.052^{b}$ & $0.214^{\mathrm{a}}$ & 5.01 & $<0.001^{*}$ \\
\hline C14:0 - myristic acid & 1.078 & 0.958 & 1.226 & 11.9 & 0.369 \\
\hline C14:1n5 - myristoleic acid & 0.097 & 0.125 & 0.133 & 6.08 & 0.214 \\
\hline C15:0 - pentadecanoic acid & 0.147 & 0.155 & 0.157 & 9.75 & 0.697 \\
\hline C16:0 - palmitic acid & $50.042^{\mathrm{a}}$ & $43.641^{b}$ & $51.037^{\mathrm{a}}$ & 7.10 & $0.050^{*}$ \\
\hline C16:1n7 - palmitoleic acid & 4.042 & 4.074 & 4.301 & 9.06 & 0.320 \\
\hline C17:0 - heptadecanoic acid & 0.225 & 0.236 & 0.241 & 2.75 & 0.876 \\
\hline C18:1 cis (n11)- vaccenic acid & 2.537 & 2.208 & 2.367 & 16.2 & 0.485 \\
\hline C18:2 n6 9c12c - linoleic acid & $35.712^{b}$ & $41.811^{\mathrm{a}}$ & $35.018^{b}$ & 5.42 & $0.017^{\star}$ \\
\hline C18:3n6 - y-linolenic acid & 0.100 & 0.148 & 0.108 & 10.6 & 0.589 \\
\hline C18:3n3 - $\alpha$-linolenic acid & $1.877^{\mathrm{b}}$ & $2.660^{\mathrm{a}}$ & $1.734^{\mathrm{b}}$ & 7.21 & $0.041^{*}$ \\
\hline C20:1(n9) - cis-11-eicosenoic acid & $0.073^{b}$ & $0.224^{\mathrm{a}}$ & $0.098^{b}$ & 10.7 & $0.034^{*}$ \\
\hline C20:2n6 - cis-11.14-eicosadienoic acid & 0.209 & 0.393 & 0.213 & 17.3 & 0.183 \\
\hline C20:3n6 - cis-8.11.14-eicosatrienoic acid & 0.333 & 0.349 & 0.293 & 12.4 & 0.285 \\
\hline C22:1n9 - erucic acid & 2.975 & 2.0816 & 2.3219 & 11.9 & 0.097 \\
\hline C20:5n3 (EPA) - cis-5,8,11,14,17- eicosapentaenoic & 0.035 & 0.024 & 0.026 & 15.3 & 0.687 \\
\hline $\mathrm{C} 22: 4 \mathrm{n} 6$ & 0.295 & 0.430 & 0.332 & 8.65 & 0.075 \\
\hline $\mathrm{C} 22: 5 \mathrm{n} 6$ & $0.000^{c}$ & $0.081^{\mathrm{a}}$ & $0.015^{b}$ & 2.87 & $<0.001^{*}$ \\
\hline $\mathrm{C} 22: 5(\mathrm{n} 3)(\mathrm{DPA})$ & 0.111 & 0.224 & 0.128 & 8.39 & 0.117 \\
\hline C22:6(n3) (DHA) - cis-4,7,10,13,16,19- docosahexaenoic acid & $0.060^{\mathrm{b}}$ & $0.141^{\mathrm{a}}$ & $0.039^{b}$ & 4.52 & $<0.001^{*}$ \\
\hline AGS & $51.542^{\mathrm{a}}$ & $45.043^{b}$ & $52.874^{\mathrm{a}}$ & 6.48 & $0.015^{*}$ \\
\hline AGMI & 9.725 & 8.713 & 9.221 & 4.95 & 0.258 \\
\hline AGPI & $38.733^{b}$ & $46.261^{\mathrm{a}}$ & $37.905^{\mathrm{b}}$ & 6.37 & $0.010^{*}$ \\
\hline Total lipids (\%) & $1.614^{\mathrm{b}}$ & $2.583^{\mathrm{a}}$ & $1.657^{\mathrm{b}}$ & 4.39 & $<0.001^{*}$ \\
\hline
\end{tabular}

${ }^{a, b}$ Different letters on the same line indicate a significant difference between groups using the Tukey test and considering $\mathrm{P} \leq$ $0.05{ }^{(*)}$.

$(P>0.05)$. Among the specific fatty acids that differed between treatments, there were: higher levels of lauric acid in T-FRA compared to the other groups; lower levels of palmitic acid in TP compared to the other groups; and higher percentages of linoleic acid, $\alpha$-linolenic acid, cis11-eicosenoic acid, C22:5n6, and cis-4,7,10,13,16,19docosahexaenoic acid in the meat of broilers from TP compared to the other two treatments $(\mathrm{P}<0.05 ;$ Table VII).

\section{Intestinal morphometry}

No histological changes were observed in the jejunum in the broilers (Figure 1). At 21 days, the crypt depth was lower in the intestine of broilers from the TN and T-FRA groups than TP; this was 

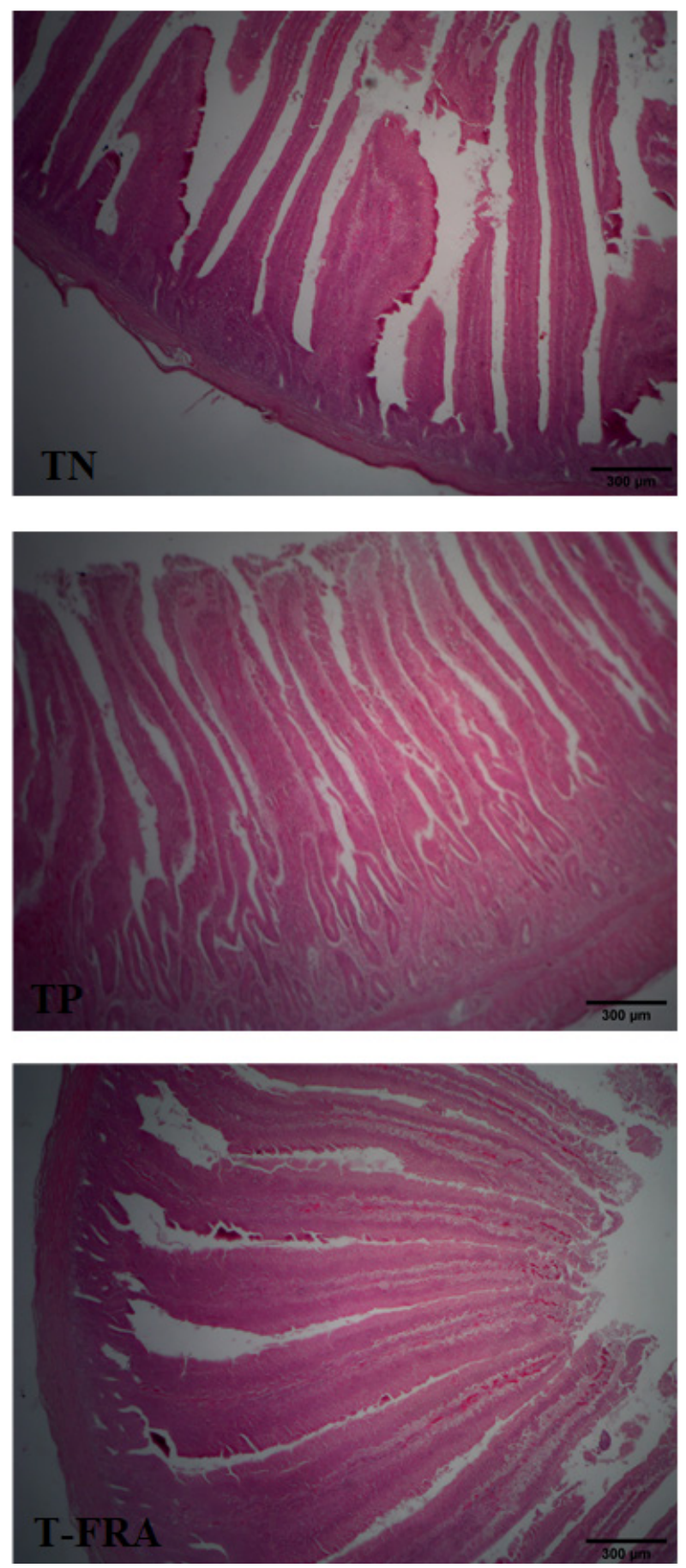

Figure 1. Histological images of broiler intestines from the negative control (TN), positive control (TP), and blend (T-FRA) treatments ( 42 days of age). No intestinal lesions were observed in birds from the three treatments at 21 and 42 days of life. consequently reflected by higher values for the villus/crypt ratio $(P<0.001$; Table VIII). At 42 days, villus height was lower in the T-FRA than in the other groups; and the crypt depth was lower in the TP and T-FRA than in TN $(P<0.001$; Table VIII). At the end of the experiment (day 42), the villus/crypt ratio was higher in the TP broilers' intestine compared to the other groups $(P<0.001)$.

\section{DISCUSSION}

Several studies indicated that medium-chain fatty acids, free or esterified, improved the production and utilization of nutrients in broilers (Van Der Aar et al. 2017, Galli et al. 2020 b). Butyric acid has been used to stimulate the development of enterocytes and consequently the performance of animals. Studies suggest that the use of butyric acid improved surface area for nutrient absorption (Reis et al. 2014). Butyric acid induces the gene expression and protein production of tight junctions, making the intestinal epithelial barrier less permeable for pathogens and toxins, which can contribute to intestinal health development and maturity (Song et al. 2017).

In recent studies, GML supplementation increased body weight, feed intake, carcass yield, and decreased feed conversion ratio in broilers, improving health (Fortuoso et al. 2019, Mustafa et al. 2019). High-fat diets containing lauric acid improved feed conversion ratio and breast yield in chickens (Zeitz et al. 2015). However, in this study, the zootechnical performance, in general, was similar between treatments; specifically, there was higher feed intake of broilers from $\mathrm{TN}$ at 21 days and a lower feed conversion ratio of broilers from T-FRA, resulting in economical benefits. The absence of difference in the body weight between the groups might be related 
Table VIII. Intestinal morphometry (villus and crypt) and villus/crypt ratio in broilers at two points in the production cycle (days 21 and 42).

\begin{tabular}{|c|c|c|c|c|c|}
\hline & Collection day & TN & TP & T-FRA & P-value \\
\hline Villus $(\mu \mathrm{m})$ & 21 & 1150.7 & 1317.0 & 1241.6 & 0.134 \\
\hline & 42 & $1283.2^{\mathrm{a}}$ & $1169.2^{\mathrm{a}}$ & $888.4^{\mathrm{b}}$ & $<0.001$ \\
\hline & & & & & \\
\hline Crypt $(\mu \mathrm{m})$ & 21 & $190.2^{\mathrm{b}}$ & $225.3^{\mathrm{a}}$ & $169.3^{\mathrm{b}}$ & $<0.001$ \\
\hline & 42 & $357.1^{\mathrm{a}}$ & $205.8^{\mathrm{b}}$ & $188.2^{\mathrm{b}}$ & $<0.001$ \\
\hline & & & & & \\
\hline Villus/crypt ratio & 21 & $6.04^{\mathrm{b}}$ & $5.84^{\mathrm{b}}$ & $7.33^{\mathrm{a}}$ & 0.010 \\
\hline & 42 & $3.59^{\mathrm{c}}$ & $5.68^{\mathrm{a}}$ & $4.72^{\mathrm{b}}$ & $<0.001$ \\
\hline
\end{tabular}

${ }^{a, b}$ Different letters on the same line indicate a significant difference between groups using the Tukey test and considering $\mathrm{P} \leq$ 0.05 .

to a conventional coccidiostat (salinomycin) in all diets, which allowed control of coccid infections, a frequent gateway for bacteria. Thus, broilers in the negative control group were not harmed by growth retardation, suggesting that anticoccidials are more critical in diets than antibiotics.

The main finding in this study is the absence of difference between treatments for the productive efficiency indexes, even though broilers consumed a diet with a reduced soy oil content and, consequently, a diet with less economical costs due to the high commercial value of soy derivatives like oil. The lower feed conversion ratio observed in the growth phase of the broilers that consumed the blend may be directly related to intestinal morphometry; that is, at 21 days, the chicks had a higher villus/crypt ratio, which is interpreted as a positive effect, as it would facilitate the process of absorption of nutrients, even in broilers consuming less feed.

Supplementation with organic and inorganic acids in the diet of broilers did not affect weight gain and feed consumption, according to Viola \& Vieira (2007), but obtained benefits regarding the feed conversion ratio similar to this study. These authors attributed the effect on feed conversion ratio to a possible reduction in intestinal microbial load due to acidifiers, with benefits in terms of intestinal cell nutrition or enzymatic activation at the intestinal level. The acidification in the poultry litter caused by the addition of organic acids in the diet also reduces the microbial load of Campylobacter and decreases the horizontal transmission of pathogens (Line 2002). The excretion of acidic waste by chickens in the litter can reduce the microbial population and consequently improve the performance of broilers. Since acidification is done naturally in broilers from the first day, the strategy is the adequate supply of organic acids to reduce the pathogenic microbiota of the gastro-intestinal tract until the end of the production phase (example 42 days). In this study, the E. coli count was numerically lower in the phases and the litter of 21-day-old broilers, which suggests the blend's antimicrobial action, confirmed using in vitro tests (MIC).

The reasons why organic acids have a nutritional influence in broilers may be an insufficient $\mathrm{HCl}$ production for diets with a high buffering capacity (high protein and 
macro elements). Eidelsburger (2001) pointed out that organic acids act on two fronts: a) antimicrobial effect (decreases the ability of bacteria with fimbria to adhere to the intestinal wall); and b) decrease in $\mathrm{pH}$ in the initial part of the TGI and, consequently, effects on the production of pepsin and digestion. Adams (1999) suggested that the efficiency of acids was due to the decrease in intracellular $\mathrm{pH}$, as they cross the microorganism's membrane in its non-dissociated state and dissociate inside the cell, changing the membrane permeability with the blocking of the substrate of the electron transport system. In turn, the cells react by eliminating protons, trying to maintain a constant $\mathrm{pH}$, increasing energy expenditure, and reducing microbial growth. Batovska et al. (2009) reported antimicrobial activity of short-chain fatty acids and their monoglycerides against gram-positive bacteria and noted that all monoglycerides were more active than their short-chain fatty acids. The MICs for $\alpha$-monolaurin obtained in the study against bacteria ranged from 7.8 to $62.5 \mu \mathrm{g} / \mathrm{ml}$, being active even against methicillin-resistant strains of Staphylococcus aureus. In the present study, the MIC of the blend was $110 \mathrm{mg}$ per $\mathrm{mL}$ against E. coli.

Research has shown that the supplementation of $\alpha$-monolaurin $(150 \mathrm{mg} /$ $\mathrm{kg}$ ) to rats for 8 weeks increased serum levels of triglycerides, LDL, and the atherogenic index, as well as reducing HDL levels (Jiang et al. 2018). Liu et al. (2020) found an increase in triglyceride levels, total cholesterol, LDL, and total antioxidant capacity comparing the group that received $300 \mathrm{mg} / \mathrm{kg}$ of $\alpha$-monolaurin. These authors suggest that the addition of $\alpha$-monolaurin may affect serum lipid and carbohydrate metabolism, corroborating the increase in blood cholesterol in the broilers in the present study. A recent study showed that GML consumption by broilers reduces total lipids in meat and reduces the percentage of saturated fatty acids while increasing the profile of unsaturated fatty acids (Valentini et al. 2020). In this study, the reverse occurred; that is, the saturated fatty acid profile increased in the meat, and polyunsaturated fatty acids decreased when the broilers consumed the blend (T-FRA). In the diet of broilers that were supplemented with the blend, soy oil content was reduced by $0.8 \%$, and the concentration of lauric acid in chicken meat increased, suggesting that the 012 present in the blend was absorbed and still deposited at the tissue level.

According to Fortuoso et al. (2020), one of the characteristics of GML is that it gives cells the ability to counteract an excess of ROS, decreasing free radicals over time in the group that received the blend. According to Valentini et al. (2020), chicken meat enriched with polyunsaturated fatty acids contains more fatty acids with a high number of double bonds, possibly affecting oxidative stability and increasing its susceptibility to oxidation. According to the literature, the lower lipid peroxidation in the intestines of chickens can be characterized initially by high non-enzymatic (thiols) and enzymatic (GST) high responses. Lipid peroxidation in cell membranes increases fluid loss due to increased ion permeability resulting in cell disruption, which leads to decreased antioxidant status and decreased degradation of free radicals, which are toxic to cells and tissues (Fortuoso et al. 2020). In the current study, the addition of the blend based on lysolecithin, $\alpha$-monolaurin, and butyric acids minimized oxidative reactions in the intestine, liver, and muscle at 42 days of age; except for the ROS levels that were higher in the jejunum on day 21, which can be a positive effect, since free radicals play an essential role in combating and controlling microorganisms. 
Oxidative stress is defined as the imbalance between the production and degradation of ROS, such as superoxide anion, hydrogen peroxide, and lipid peroxides (Delles et al. 2014). The supplementation of the blend may have minimized the impacts caused by this biochemical reaction at the tissue. The increase in antioxidants in these tissues is the most likely explanation for reducing ROS and TBARS since antioxidants are essential to balance oxidative reactions and protect tissues. Therefore, tissue oxidant/antioxidant ratios combined with intestinal morphometry suggest that the tested antimicrobial blend had positive effects on intestinal health.

Monolaurin and butyrate for antimicrobial properties and have an effect on intestinal health for AGP replacement, mainly by stimulating enterocytes. Lysolecithins as fat emulsifier for fat replacement, which allowed to reduce the amount of soy oil in the diet. These nutritional properties of the blend have desirable characteristics for the production system.

\section{CONCLUSION}

The inclusion of the commercial blend based on lysolecithin, $\alpha$-monolaurin, and butyric acids positively influenced feed conversion and kept the other performance parameters, even with the reduction of oil in the treatment containing T-FRA, even without the presence of growth promoters. There was increased cholesterol concentrations and balanced the oxidant/ antioxidant status at the tissue level. The diet that used the blend, had oil-sparing effects (reduction of $0.8 \%$ ). Regarding the quality of the meat, the blend had positive and negative effects; that is, it positively affected oxidation and antioxidant levels, while the increase in saturated fatty acids associated with a reduction in polyunsaturated fat is an undesirable effect for consumers.

\section{REFERENCES}

ADAMS CA. 1999. Oxidation and antioxidants. Nutricines: food componentes in health and nutrition. Nottingham: Nottingham University Press 2: 11-32.

ALI SF, LEBEL CP \& BONDY SC 1992. Reactive oxygen species formation as a biomarker of methylmercury and trimethyltin neurotoxicity. Neurotoxicol 13(3): 637-648.

ARAÚJO JMA. 2011. Química de Alimentos: teoria e prática. Viçosa, MG. UFV.

BATOVSKA DI, TODOROVA IT, TSVETKOVA IV \& NAJDENSKI HM. 2009. Antibacterial study of the médium chain fatty acids and their 1-monoglycerides: individual effects and synergistic relationships. Pol J Microbiol 58(1): 43-47.

BLIGH EG \& DYER WJ. 1959. A rapid method of total lipid extraction and purification. Can J Biochem Physiol 37(21): 911-917.

CARUSO M \& DEMONTE A. 2005. Histomorfometria do intestino delgado de ratos submetidos a diferentes fontes protéicas. Alim Nutr 16: 131-136.

COSTA CM, SANTOS RCC \& LIMA ES. 2006. A simple automated procedure for thiol measurement in human serum samples. J Bras Patol Med Lab 42: 345-350.

DELLES RM, XIONG YL, TRUE AD, AO T \& DAWSON KA. 2014. Dietary antioxidant supplementation enhances lipid and protein oxidative stability of chicken broiler meat through promotion of antioxidant enzyme activity. Poult Sci 93(6): 1561-1570.

DIBNER JL \& BUTTIN P. 2002. Use of Organic Acids as a Model to Study the Impact of Gut Microflora on Nutrition and Metabolism. J Appl Poult Res 11(4): 453-463.

EIDELSBURGER U. 2001. Feeding short-chain organic acids to pigs. Nottingham. Nottingham University Press, p. 107-121.

FONSECA SS, DA SILVA VC, VALENTIM JK \& GERALDO A. 2018. Efeito da adição de diferentes emulsificantes na dieta sobre o rendimento de carcaça de frangos de corte. Rev Acad Ciên Anim 16: 1-13.

FORTUOSO BF ET AL. 2020. Effects of glycerol monolaurate on growth and physiology of chicks consuming diet containing fumonisin. Microb Pathog 147: 104261. 
FORTUOSO BF ET AL. 2019. Glycerol monolaurate in the diet of broiler chickens replacing conventional antimicrobials: Impact on health, performance and meat quality. Microb Pathog 129: 161-167.

FREITAS L, SANTOS JC, BARCZA MV \& CASTRO HF. 2009. Alternativa potencial para aproveitamento do glicerol gerado na produção de biodiesel: síntese enzimática de monolaurina por esterificação. Quím Nova 32: 2277-2281.

FUINI MG. 2001. Utilização do cogumelo Agaricus blazei como alternativa ao uso de antibióticos em rações para frangos de corte. 64 p. Dissertação (Mestrado em Zootecnia) - Universidade Federal de Lavras. (Unpublished).

GALLI GM ET AL. 2020b. Growth performance and meat quality of broilers fed with microencapsulated organic acids. An Feed Sci Technol 271: 114706.

GALLI GM ET AL. 2020a. Combination of herbal components (curcumin, carvacrol, thymol, cinnamaldehyde) in broiler chicken feed: Impacts on response parameters, performance, fatty acid profiles, meat quality and control of coccidia and bactéria. Microb Pathog 139: 103916.

HABIG WH, PABST MJ \& JAKOBY WB. 1974. Glutathione S-transferases. The first enzymatic step in mercapturic acid formation. J Biol Chem 249(22): 7130-7139.

HARTMAN L \& LAGO RC. 1973. Rapid preparation of fatty acid methyl esters from lipids. Lab Pract 22(494): 475-477.

JIANG Z, ZHANG MZH, LI Y, LIU M \& FENG F. 2018. Antimicrobial emulsifier-glycerol monolaurate induces metabolic syndrome, gut microbiota dysbiosis, and systemic lowgrade inflammation in low-fat diet fed mice. Mol Nutr Food Res 62(3): 29131494.

LIEBERMAN S, ENIG M \& PREUSS HG. 2006. A review of monolaurin and lauric acid. Nat Viruc Bacter Agen 12(6): 310-314.

LINE JE. 2002. Campylobacter and Salmonella populations associated with chickens raised on acidified litter. Poult Sci 81: 1473-1477.

LIU T, LI C, ZHONG H \& FENG F. 2020. Dietary medium-chain $\alpha$-monoglycerides increase BW, feed intake, and carcass yield in broilers with muscle composition alteration. Poult Sci 100(1): 186-195.

MUSTAFA NG. 2019. Biochemical trails associated with different doses of alpha-monolaurin in chicks. Adv Anim vet Sci 7: 187-192.

OHKAWA H, OHISHI N \& YAGI K. 1979. Assay for lipid peroxidation in animal tissue by thiobarbituric acid reaction. Anal Biochem 95: 351-358.
REIS MP, RODRIGUES PB, DE SOUZA CANTARELLI V, MENEGHETTI C, AMANDIO A, JUNIOR AAPG, DE LIMA RR, FASSANI EJ \& DE PAULA NAVES L. 2014. Levels of zinc bacitracin used to improve the performance of broilers. Ciênc Rural 44: 1093-1099.

RICKE SC. 2003. Perspectives on the use of organic acids and short chain fatty acids as antimicrobials. Poult Sci 82(4): 632-639.

ROCHA AP, ABREU RD, COSTA MCMM, OLIVEIRA GJC, ALBINATI RCB, PAZ AS, QUEIROZ LG \& PEDREIRA TM. 2010. Prebióticos, ácidos orgânicos e probióticos em rações para frangos de corte. Rev Bras Saúde Prod Anim 11(3): 793-801.

ROSTAGNO H, ALBINO LFT, DONZELE J, GOMES PC, OLIVEIRA RF, LOPES DC, FERREIRA AS, BARRETO SL \& EUCLIDES RF. 2011. Tabelas Brasileiras Para Aves e Suínos: Composição de Alimentos e Exigências Nutricionais. Composição de alimentos e exigências nutricionais.

SONG B, LI H, WU Y, ZHEN W, WANG Z, XIA Z \& GUO Y. 2017. Effect of microencapsulated sodium butyrate dietary supplementation on growth performance and intestinal barrier function of broiler chickens infected with necrotic enteritis. An Feed Sci Technol 232: 6-15.

VALENTINI J ET AL. 2020. Chemical composition, lipid peroxidation, and fatty acid profile in meat of broilers fed with glycerol monolaurate additive. Food Chem 330: 127187.

VAN DER AAR P, MOLIST F \& VAN DER KLIS JD. 2017. The central role of intestinal health on the effect of feed additives on feed intake in swine and poultry. Na Feed Sci Technol 233: 64-75.

VISENTAINER JV. 2012. Aspectos analíticos da resposta do detector de ionização em chama para ésteres de ácidos graxos em biodiesel e alimentos. Quím Nova 35(2): 274-279.

VIOLA ES \& VIEIRA SL. 2007. Suplementação de acidificantes orgânicos e inorgânicos em dietas para frangos de corte: desempenho zootécnico e morfologia intestinal. Rev Bras Zootec 36(4): 1097-1104.

ZEITZ JO, FENNHOFF J, KLUGE H, STANG GI \& EDER K. 2015. Effects of dietary fats rich in lauric and myristic acid on performance, intestinal morphology, gut microbes, and meat quality in broilers. Poul Sci 94(10): 2404-2413.

ZHAO PY, LI HL, HOSSAIN MM \& KIM IH. 2015. Effect of emulsifier (lysophospholipids) on growth performance, nutrient digestibility and blood profi le in weanling pigs. An Feed Sci Technol 207: 190-195. 


\section{SUPPLEMENTARY MATERIAL}

\section{Table SI.}

\section{How to cite}

ALMEIDA AB ET AL. 2021. Use of blend based on an emulsifier, monolaurin, and glycerides of butyric acid in the diet of broilers: impacts on intestinal health, performance, and meat. An Acad Bras Cienc 93: e20210687. DOI 10.1590/0001-3765202120210687.

Manuscript received on May 6, 2021;

accepted for publication on August 20, 2021

\section{AMANDA B. ALMEIDA ${ }^{1}$}

https://orcid.org/0000-0001-6910-7904

\section{DENISE N. ARAÚJO²}

https://orcid.org/0000-0001-9606-5447

\section{JOÃO V. STRAPAZZON}

https://orcid.org/0000-0002-3005-9148

\section{CLEICIANE RITA ${ }^{2}$}

https://orcid.org/0000-0001-7656-7167

\section{AMANDA DILDA ${ }^{2}$}

https://orcid.org/0000-0002-6802-1698

GIOVANA BALEN ${ }^{2}$

https://orcid.org/0000-0002-7943-7891

\section{GUILHERME L. DEOLINDO ${ }^{1}$}

https://orcid.org/0000-0001-9734-6902

\section{DANIELA NESI ${ }^{2}$}

https://orcid.org/0000-0002-2132-7040

\section{VALCENIR J.M. FURLAN ${ }^{3}$}

https://orcid.org/0000-0003-0457-0687

GIOVANA PELISSER ${ }^{4}$

https://orcid.org/0000-0003-4821-8247

\section{RICARDO E. MENDES ${ }^{4}$}

https://orcid.org/0000-0001-9222-3479

MATEUS FRACASSO 4

https://orcid.org/0000-0002-6680-9457

\section{ROGER WAGNER ${ }^{5}$}

https://orcid.org/0000-0002-5943-4909

MARCEL M. BOIAGO

https://orcid.org/0000-0002-0950-4577

\section{ALEKSANDRO S. DA SILVA ${ }^{2}$}

https://orcid.org/0000-0001-5459-3823

${ }^{1}$ Programa de Pós-Graduação de Zootecnia, Universidade do Estado de Santa Catarina (UDESC), Rua Beloni Trombeta Zanin, 680E, Santo Antônio, 89815-630 Chapecó, SC, Brazil

${ }^{2}$ Universidade do Estado de Santa Catarina (UDESC), Departamento de Zootecnia, Rua Beloni Trombeta Zanin, 680E, Santo Antônio, 89815-630 Chapecó, SC, Brazil

${ }^{3}$ Universidade Federal do PAMPA, Departamento de Ciência de Alimentos, Rua Luiz Joaquim de Sá Brito, s/n, 97650-000 Itaqui, RS, Brazil

${ }^{4}$ Centro de Diagnóstico e Pesquisa em Patologia Veterinária, Instituto Federal Catarinense (IFC), Rodovia SC 283, Km 17, 89703-720 Concordia, SC, Brazil

${ }^{5}$ Universidade Federal de Santa Maria, Departamento de Ciência e Tecnologia de Alimentos, Av. Roraima, 1000, Cidade Universitária, Camobi, 97105-900 Santa Maria, RS, Brazil

Correspondence to: Denise N. Araújo, Aleksandro S. Da Silva E-mail:denise.araujo@udesc.br; aleksandro_ss@yahoo.com.br

\section{Author contributions}

Almeida AB, Araújo DN, Boiago MM and Da Silva A.S. contributed to the design and implementation of the research, to the analysis of the results. Wagner $\mathrm{R}$ and Mendes RE helped in the elaboration of the project and its execution and financing. Strapazzon JV, Rita C, Dilda A, and Balen G participated in the execution of the experiment and collection of samples and data. Deolindo GL, Nesi D, Furlan VJM, Pelisser G, and Fracasso MA did the laboratory analysis. All authors discussed the results and contributed to the final manuscript.

\section{(cc) BY}

